\title{
Variability in Phytochemical Contents and Biological Potential of Pomegranate (Punica granatum) Peel Extracts: Toward a New Opportunity for Minced Beef Meat Preservation
}

\author{
Mariam Fourati, ${ }^{1}$ Slim Smaoui $\mathbb{D}^{1},{ }^{1}$ Hajer Ben Hlima, ${ }^{2}$ Khaoula Elhadef, ${ }^{1}$ \\ Ahlem Chakchouk Mtibaa, ${ }^{1}$ and Lotfi Mellouli ${ }^{1}$ \\ ${ }^{1}$ Laboratory of Microorganisms and Biomolecules, Center of Biotechnology of Sfax, University of Sfax, \\ Road of Sidi Mansour Km 6, P.O. Box 1177, Sfax 3018, Tunisia \\ ${ }^{2}$ Algae Biotechnology Unit, Biological Engineering Department, National School of Engineers of Sfax, University of Sfax, \\ Sfax 3038, Tunisia \\ Correspondence should be addressed to Slim Smaoui; slim.smaoui@cbs.rnrt.tn
}

Received 16 June 2020; Revised 25 July 2020; Accepted 9 September 2020; Published 30 September 2020

Academic Editor: Teresa Zotta

Copyright (c) 2020 Mariam Fourati et al. This is an open access article distributed under the Creative Commons Attribution License, which permits unrestricted use, distribution, and reproduction in any medium, provided the original work is properly cited.

\begin{abstract}
Extraction of Tunisian pomegranate peels was employed with different solvents such as ethyl acetate, acetonitrile, and water. Total phenolic and flavonoids contents, antioxidant activity, and antibacterial capacity against five foodborne pathogenic bacteria were evaluated. The highest values of polyphenols (351 mg gallic acid equivalent/g), flavonoids (104 mg quercetin/g), and DPPH and ABTS inhibition were recorded in the ethyl acetate extract followed by the aqueous extract. The latter present the maximum antibacterial potential against $S$. enterica, $P$. aeruginosa, and E. coli. The potential use of the lyophilized aqueous extract (AE), used for safety reason and being rich in phenolic, as biopreservative in minced beef meat was described. AE was incorporated at $0.1,0.5$, and $1 \%$ and compared with $0.1 \%$ butylated hydroxytoluene (BHT). During 21 days at $4{ }^{\circ} \mathrm{C}, \mathrm{AE}$ at $1 \%$ could appreciably retard the microflora proliferation $(p<0.05)$, the accumulation of MetMb and the carbonyl group $(p<0.05)$, slowing down the loss of sulphydryl proteins $(p<0.05)$, and led to a decrease $(p<0.05)$ in primary (peroxide value and conjugated dienes) and secondary lipid oxidation (TBARS) in treated meat. By the $14^{\text {th }}$ day, AE-treated minced meat obtained higher sensory scores than untreated and BHT samples. Based on these results, lipid and protein oxidation changes and sensorial attributes were useful in discriminating meat samples by overall acceptability prediction. Generally, AE at $1 \%$ presented the potent preservative effect that could be utilized as an application on meat-substituting synthetic antioxidant.
\end{abstract}

\section{Introduction}

The minced meat has been targeted as one of the main foods that deserve expanded attention. Consequently, the safety of meat is of major concern to consumers, food industries, government agencies, public health professionals, researchers, and the general public locally, nationally, and internationally $[1,2]$. On the other hand, it is well known that minced meat was judged as principle substrate maintaining the development of several spoilage and pathogenic bacteria, leading then to a loss of product quality [3]. Equally, lipid and protein oxidation in meat mincing conducted to a quick quality deterioration causes changes in nutritional and sensory quality (flavor, texture, and color) $[4,5]$. To prevent oxidative degradation, food industry used synthetic antioxidants such as butylated hydroxytoluene (BHT) and butylated hydroxyanisole (BHA) demonstrating a toxical effect as reported in recent studies [6]. For this reason, current scientific research studies tried to find alternative antioxidants obtained from natural sources $[7,8]$ and tested as strong preservative to be incorporated in different meat products $[6,7,9-15]$.

Pomegranate fruit parts, such as arils, peels, and rinds, were famous by their elevated antioxidants concentration 
showing various activities [6]. Pomegranate peel application has been studied in beef meat $[8,16,17]$, cooked chicken products [18-21], cooked goat meat [22], and pork meat $[23,24]$.

In Tunisia, more than sixty pomegranate cultivars have been identified and biologically characterized [25-28], but unfortunately, little data are existing on their biological potential and application in food systems. This study aimed to investigate (i) the impact of three different extracting solvents ethyl acetate, acetonitrile, and water on phytochemical contents and antibacterial potency in Tunisian pomegranate peel, and (ii) the evaluation of the aqueous pomegranate peel extract at different levels on the raw minced beef and their effect on overall acceptability.

\section{Materials and Methods}

2.1. Plant Material and Extraction. Pomegranate peels, collected from farms located in Sfax, Tunisia (N: $34.4426^{\circ}$, E: $\left.10.4537^{\circ}\right)$, were dried and powdered. During $24 \mathrm{~h}$, powdered peel (100 g) was extracted with ethyl acetate, acetonitrile, and water at a ratio of $1: 3$. Therefore, supernatants were concentrated in a rotary evaporator gaining a yellow-brown residue that was immediately analyzed.

2.2. Phytochemical Analysis. Total phenolic content (TPC) was assessed by the Folin-Ciocalteu method according to Singleton and Rossi [29]. Moreover, gallic acid (GA) was used as a standard, and TPC was expressed as mgGA equivalents/g sample.

Total flavonoid content (TFC) was evaluated according to the method reported by Quettier-Deleu et al. [30]. Besides, quercetin $(\mathrm{QE})$ was utilized as a standard, and the results were expressed as milligrams of quercetin equivalents (mg QE)/g of the peel extract.

\subsection{Antioxidant Activity}

2.3.1. DPPH Assay. According to Bersuder et al. [31], DPPH radical scavenging activity of the extract at $50 \mu \mathrm{g} / \mathrm{mL}$ was evaluated by using a spectrometer at $517 \mathrm{~nm}$. The control was handled in the same manner with the exception of using distilled water in place of the extract. Moreover, the chosen standard was butylated hydroxyanisole (BHA). Free radical scavenging activity (\%) was calculated as follows:

$$
\% \mathrm{DPPH} \text {-scavenging activity }=\left[\frac{\left(A_{\text {Control }}-A_{\text {Sample }}\right)}{A_{\text {Control }}}\right] \times 100,
$$

where $A_{\text {Control }}$ is the initial DPPH solution's absorbance at $517 \mathrm{~nm}$, and $A_{\text {Sample }}$ is the concentration of DPPH when the extract and positive control were present.

2.3.2. ABTS Cation Radical Decolorization Assay. The ABTS $^{\bullet+}$ scavenging activity was determined by the method described Re et al. [32]. Twenty microliters of each extract at $50 \mu \mathrm{g} / \mathrm{mL}$ were supplemented to $180 \mu \mathrm{L}$ of working $\mathrm{ABTS}^{\bullet+}$ solution and subsequently incubated at room temperature for $6 \mathrm{~min}$ in the dark. Absorbance was measured at $734 \mathrm{~nm}$ using ethanol as a control and ascorbic acid as an antioxidant standard:

$$
\% \mathrm{ABTS}^{\bullet+} \text {-scavenging activity }=\left[\frac{\left(A_{\text {Control }}-A_{\text {Sample }}\right)}{A_{\text {Control }}}\right] \times 100 \text {, }
$$

where $A_{\text {Control }}$ is the initial concentration of the $\mathrm{ABTS}^{\bullet+}$ and $A_{\text {Sample }}$ is the absorbance of the extract sample.

\subsection{Antibacterial Activity}

\subsubsection{Bacterial Strains and Culture Conditions.} Purchased from American Type Culture Collection, five target bacteria strains, namely, Staphylococcus aureus ATCC 6538, Listeria monocytogenes ATCC 19117, Salmonella enterica ATCC 43972, Escherichia coli ATCC 8739, and Pseudomonas aeruginosa ATCC 4912 were used. Indicator bacteria were grown overnight in Muller-Hinton broth $(\mathrm{MH})$ at $30^{\circ} \mathrm{C}$ for $L$. monocytogenes, P. aeruginosa, and S. enterica and at $37^{\circ} \mathrm{C}$ for S. aureus and E. coli. For each bacterium, $10^{6} \mathrm{CFU} / \mathrm{mL}$ was the final inoculum concentration appropriate to antagonist tests.

2.4.2. Agar Diffusion Method. As described by Güven et al. [33], antibacterial activity of each extract was evaluated by agar well diffusion assays. A volume of $50 \mathrm{~mL}$ of the molten agar were transferred into sterile Petri ( $\varnothing 90 \mathrm{~mm}$ ) dishes. Then, $100 \mu \mathrm{l}$ of this suspension was spread on $\mathrm{MH}$ plates. Once the plates had been aseptically dried, wells of $6 \mathrm{~mm}$ diameter were punched in the seeded agar using sterile Pasteur pipette. Each well was loaded with $50 \mu \mathrm{l}$ of each extract at $0.6,1.25,2.5,5,10,20,30$, and $40 \mathrm{mg} / \mathrm{mL}$, and plates were incubated at $37^{\circ} \mathrm{C}$ during $24 \mathrm{~h}$. Antibacterial activity was evaluated by assessing the diameter of circular inhibition zones around the well.

2.4.3. Determination of MIC. Minimum inhibitory concentrations (MICs) of each extract against all target strains were assessed based on the microdilution method [34]. Expressed by $\mathrm{mg} / \mathrm{mL}$, MIC was the lowest concentration that inhibited the visible growth of each tested bacterium.

2.5. Minced Beef Meat Samples Preparation. Fresh beef meat was delivered by a regional slaughterhouse located in Sfax (Tunisia), was minced by a sterile grinder, and was divided in 5 lots. Lyophilized powder of the water extract (AE) was added at $0.1 \%(15.256 \mathrm{mg} \mathrm{GAE} / \mathrm{g}): \mathrm{AE} 1 ; 0.5 \%(76.28 \mathrm{mg}$ GAE/g): AE2, and 1\% (152.56 mg GAE/g): AE3. Controls (without antioxidant and BHT at $0.01 \%$ [35]) were equally studied. Eventually, all samples were kept for 21 days at $4^{\circ} \mathrm{C}$, and quality characteristics were examined in days $0,3,7,14$, and 21 . 


\subsection{Analysis of Meat Samples}

2.6.1. Microbiological Analysis. Twenty-five grams of meat sample were homogenized in $225 \mathrm{~mL}$ of sterile buffered peptone water solution at $0.1 \% .100 \mu \mathrm{L}$ of serial decimal dilutions was prepared and plated onto the corresponding agar. To enumerate selected colonies, aerobic plate counts (APC) was determined on plate count agar (PCA, Oxoid, UK) and incubated at $30^{\circ} \mathrm{C}$ for $48 \mathrm{~h}$ [36]. Psychrotrophic total counts (PTC) was determined as described above for $\mathrm{APC}$ and incubated at $7^{\circ} \mathrm{C}$ for 10 days [37]. Enterobacteriaceae counts was calculated on violet red bile glucose medium (VRBG, Oxoid, UK) and incubated at $37^{\circ} \mathrm{C}$ for $24 \mathrm{~h}$ [38].

\subsubsection{Physicochemical Analysis Methods}

(1) $\mathrm{pH}$ Analysis. According to Özyurt et al. method, $\mathrm{pH}$ of all meat samples was assessed [39]. At each sampling point, the $\mathrm{pH}$ was determined using a $\mathrm{pH}$ meter.

(2) Evaluation of Protein Oxidation. Based on these absorbance values, MetMb (\%) was evaluated by using the following formula [7]:

$$
\operatorname{MetMb}(\%)=\left[-2.51\left(\frac{A_{572}}{A_{525}}\right)+0.777\left(\frac{A_{565}}{A_{525}}\right)+0.8\left(\frac{A_{545}}{A_{525}}\right)+1.098\right] \times 100 .
$$

Carbonyl groups evaluation was assessed according to Jiménez-Martín et al. [40] method. Carbonyl content was identified in accordance with a molar extinction coefficient equal to $22000 \mathrm{M}^{-1} \cdot \mathrm{cm}^{-1}$ and expressed in $\mathrm{nmol}$ carbonyl/mg of protein. As described by Cando et al. [41], sulphydryl groups were evaluated by using the of $5,5^{\prime}$ dithio-bis-(2-nitrobenzoic acid) method. Sulphydryl groups were calculated using a molar extinction coefficient of $13600 \mathrm{M}^{-1} \cdot \mathrm{cm}^{-1}$, and results were expressed in $\mathrm{mmol}$ sulphydryl/g of protein.

(3) Evaluation of Lipid Oxidation in Beef Meat. According to Hur et al. [42], peroxide value (PV) was assessed and expressed in meq of peroxide $/ \mathrm{kg}$ of meat.

The TBARS experiment method was evaluated by Eymard et al. [43] method. TBARS values were expressed as $\mathrm{mg}$ of malonaldehyde equivalent per $\mathrm{kg}$ of sample $(\mathrm{mg}$ MDA eq $/ \mathrm{kg}$ of meat) by using molar extinction coefficient of the MDA-TBA adducts at $532 \mathrm{~nm}\left(1.56 \times 10^{5} \mathrm{M}^{-1} \cdot \mathrm{cm}^{-1}\right)$ [43].

According to Juntachote et al. [44], conjugated dienes (CDs) were evaluated, and results were expressed as $\mu \mathrm{mol} /$ mg of meat sample.

2.6.3. Sensory Evaluation. A twenty-member panel trained on the classifying beef meat color, appearance, odor, and overall acceptability evaluated sensory traits. Sensory attributes were evaluated using nine-point $(1=$ very bad and $9=$ very good) scores scales. A score below 5 indicated the sample being unacceptable.
2.7. Statistical Analysis. For each parameter, a one-way ANOVA with 2 factors, treatments and storage time, was realized by using SPSS 19. To test the statistical significance, Tukey's post hoc was used. By using Durbin-Watson statistic tests at $(p<0.05)$, relationships between overall acceptability and sensory characteristics were established.

\section{Results and Discussion}

\subsection{Phytochemical Content, Antioxidant Activity, and Antibacterial Activity}

3.1.1. TPC and TFC. Studied phytochemical content of extracts from pomegranate peel is displayed in Table 1. The greatest concentration of phenolic compounds (391.515 $\pm 10.58 \mathrm{mg}$ of GAE/g) was presented in ethyl acetate fraction. Belkacem et al. [45] and Barathikannan et al. [46] reported an ethyl acetate TPC equal to $597.08 \pm 3.9$ and $218.152 \pm 1.73 \mathrm{mg} \mathrm{GAE} / \mathrm{g}$ of the extract, respectively.

The ethyl acetate extract revealed the highest values of TFC with $104.128 \pm 3.69 \mathrm{mg}$ QE/g. In fact, TFC/TPC represents a range between 24.93 and $27.89 \%$ (Table 1). Our data approve the studies compared to total polyphenols in pomegranate peel, which was, respectively, $24 \%$ and $30 \%$.

3.1.2. Evolution of Antioxidant Properties. The most widely used methods for antioxidant capacity evaluation were the ABTS and DPPH radicals. According to Rufino et al. [47], aqueous/organic extracts with hydrophilic and lipophilic compounds were generally treated by the DPPH method, and antioxidant activity of hydrophilic compounds was commonly analyzed by the ABTS method.

(1) DPPH Free Radical Scavenging Activity. DPPH free radical scavenging activities are exposed in Table 1 . The scavenging activity of the three fractions analyzed was evaluated to those of BHA, used as a positive control, and was found to be concentration-dependent. DPPH scavenging activity of ethyl acetate fraction (88.56\%) was superior to acetonitrile (84.24\%) followed by water (80.12\%). Consecutively, DPPH free radical scavenging activity of pomegranate peel extracts was ranged as follows: ethyl acetate $>\mathrm{BHA}>$ acetonitrile $>$ water (Table 1). It has been reported that DPPH activity is deeply influenced by the phenolic compounds of pomegranate peel extracts [48-50]. In previous studies, when studying the relationship between the DPPH scavenging activity and total phenolic content, Wang et al. [51] have reported that pomegranate peel extracts with elevated total phenolic content reveled an advanced DPPH scavenging activity and vice versa.

(2) ABTS Radical Scavenging Activity. The different solvents of pomegranate peel extraction showed a concentrationdependent manner (65.26-77.12\%) in the ABTS radical scavenging assay with the greatest level illustrated in the ethyl acetate extract (Table 1). This activity was ranged as BHA > ethyl acetate $>$ acetonitrile $>$ water in all pomegranate peel extracts. This result proposes that maximum of the 
TABLE 1: Total phenolic and flavonoids contents and antioxidant activity of the ethyl acetate, acetonitrile, and aqueous extracts of Punica granatum (pomegranate) peel.

\begin{tabular}{lcccc} 
& TPC $(\mathrm{mg} \mathrm{GAE} / \mathrm{g})$ & \multirow{2}{*}{ TFC $(\mathrm{mg} \mathrm{QE} / \mathrm{g})$} & \multicolumn{2}{c}{ Antioxidant activity } \\
& & & DPPH assay $(\%)$ & ABTS assay $(\%)$ \\
\hline Ethyl acetate & $391.51 \pm 10.58^{\mathrm{d}}$ & $104.12 \pm 3.69^{\mathrm{c}}$ & $88.56 \pm 1.52^{\mathrm{d}}$ & $77.12 \pm 1.57^{\mathrm{c}}$ \\
Acetonitrile & $281.13 \pm 19.25^{\mathrm{c}}$ & $76.88 \pm 6.39^{\mathrm{b}}$ & $84.24 \pm 1.25^{\mathrm{b}}$ & $71.89 \pm 0.32^{\mathrm{b}}$ \\
Water & $178.25 \pm 6.22^{\mathrm{b}}$ & $44.45 \pm 2.05^{\mathrm{a}}$ & $80.12 \pm 1.88^{\mathrm{a}}$ & $65.26 \pm 1.96^{\mathrm{a}}$ \\
BHA & - & - & $86.28 \pm 0.97^{\mathrm{c}}$ & $81.19 \pm 2.12^{\mathrm{d}}$ \\
\hline
\end{tabular}

\pm , standard deviation of three replicates; values with a different letter (a-d) within a column are significantly different $(p<0.05)($ Tukey's test).

antioxidant capacity of pomegranate extracts results from the contribution of TPC and TFC.

\subsection{Antimicrobial Activities of Punica granatum Extracts.} For Gram-positive bacteria, the results presented that the highest diameters of the inhibition zone (IZ) at the concentration of $40 \mathrm{mg} / \mathrm{mL}$ pertained to the ethyl acetate extract at $24.00 \pm 0.50$ and $25.50 \pm 1.00 \mathrm{~mm}$, respectively (Table 2). Thus, the highest anti-L. monocytogenes activity and antiS. aureus activity were recorded for the ethyl acetate extract, followed by the water and acetonitrile peel extracts. As presented in Table 2, a high correlation $\left(R^{2}>0.703\right)$ between IZ and concentrations was revealed. For Listeria monocytogenes, the regression coefficients of the ethyl acetate extract inhibition zone ( $\left.\mathrm{IZ}_{\mathrm{EA}}\right)$ were 1.31 and 1.34 times higher than $\mathrm{IZ}_{\mathrm{A}}$ (aqueous extract inhibition zone) and $\mathrm{IZ}_{\mathrm{A}}$ (acetonitrile extract inhibition zone), respectively. Furthermore, for Staphylococcus aureus, the regression coefficients of $\mathrm{IZ}_{\mathrm{EA}}$ were 1.05 and 1.26 times higher than $\mathrm{IZ}_{\mathrm{W}}$ and $\mathrm{IZ}_{\mathrm{A}}$, respectively.

In the case of Pseudomonas aeruginosa and Escherichia coli, Gram-negative bacteria, the highest inhibitory effect was noted for the peel extracts obtained using the water extraction at $40 \mathrm{mg} / \mathrm{mL}$. In fact, the measured inhibition zones were $21.75 \pm 0.75$ and $23.25 \pm 1.25 \mathrm{~mm}$, respectively (Table 2 ). The pomegranate peel extracts showed the anti- $P$. aeruginos $a$ and $E$. coli activities in the order of water $>$ ethyl acetate $>$ acetonitrile (Table 2). Our results approved with those previously described by Voravuthikunchai et al. [52]. The water peel extracts of pomegranate peel showed antibacterial activity against six strains of $E$. coli.

In the case of $S$. enterica, at $40 \mathrm{mg} / \mathrm{mL}$, the observed inhibition zones ranged from $18.75 \pm 0.75$ (acetonitrile extract) to $22.75 \pm 1.25 \mathrm{~mm}$ (water extract). In the case of S. enterica, at $40 \mathrm{mg} / \mathrm{mL}$, the observed inhibition zones ranged from $18.75 \pm 0.75$ (acetonitrile extract) to $22.75 \pm 1.25 \mathrm{~mm}$ (water extract). It should be noted that the regression coefficients of $\mathrm{IZ}_{\mathrm{W}}$ were 1.18 and 1.33 times higher than $\mathrm{IZ}_{\mathrm{EA}}$ and $\mathrm{IZ}_{\mathrm{A}}$, respectively (Table 2). The results of this study exhibited thus that the extracts obtained from pomegranate revealed antibacterial activity against the five foodborne pathogens and tested bacteria. The activity of Punica granatum extracts against Salmonella was also established in the studies by Choi et al. [53] and Hayrapetyan et al. [54].

3.3. MIC Determination of Extracts. The effects of pomegranate peel extracts on $L$. monocytogenes, $S$. aureus, $S$. enterica, $P$. aeruginosa, and E. coli proliferation are listed in Table 3. They revealed different extends of antibacterial potential against all tested strains, and they were most active against Gram-positive bacteria $S$. aureus and L. monocytogenes with a MIC ranged between 0.60 and $2.50 \mathrm{mg} / \mathrm{mL}$. At the same time, $\mathrm{Naz}$ et al. reported that the activity against Gram-positive organisms was more elevated compared to Gram-negative species [55]. This low CMI found in Gram-negative bacteria was explained by their outer lipopolysaccharide membranes that makes them more resistant to various antimicrobials [56]. In fact, in our study, Table 3 shows that the MIC against E. coli was at least two-fold less than that of $S$. enteric. Others studies reported the MIC against several strains of $E$. coli which ranged from 0.39 to $25 \mathrm{mg} / \mathrm{mL}[52,57]$. Also, Voravuthikunchai et al. investigated that the peels aqueous extract at $0.5-3 \mathrm{mg} / \mathrm{mL}$ (MIC) can inhibit enterohemorrhagic E. coli O157: H7 [58].

Changes in results of peel extracts profile may be clarified by the extraction solvents differentiation, the plant variety, and then geographical and the climatic conditions variations [49]. Indeed, authors recorded MIC against $\mathrm{Gram}^{+}$S. aureus and $\mathrm{Gram}^{-}$Salmonella ranged, respectively, from 0.62 to $\geq 250 \mathrm{mg} / \mathrm{mL}$ [53-55] and from 10.75 to $12.5 \mathrm{mg} / \mathrm{mL}$ [18] when using Punica granatum extracts.

3.4. Effect of the Pomegranate Peel Aqueous Extract on Conservation of Raw Minced Beef Meat at $4^{\circ} \mathrm{C}$. Between the organic solvents used for the extraction from peel pomegranate, water was preferred in the food application over ethyl acetate and acetonitrile for safety reasons. At the same potential in antioxidant and antibacterial activities, the less safe use made ethyl acetate and acetonitrile undesirable solvents, so the subsequent experiments; for preservation of meat sample, the water extract at different concentrations was used. In this second part, the aqueous extract (AE) was supplemented to the meat sample at $0.1,0.5$, and $1 \%$.

\subsubsection{Physicochemical Analyses}

(1) $p H$. Figure 1 presents the effect of AE used in raw minced beef meat samples on the $\mathrm{pH}$ during 21 days of storage at $4^{\circ} \mathrm{C}$. Statistically, $\mathrm{pH}$ values showed a slightly significant increase $(p<0.05)$ in treated samples during 21 days of storage with the lowest recorded in samples treated with $\mathrm{AE}$ at $1 \%(6.14 \pm 0.17)$ and the highest in control samples $(7.11 \pm 0.20)$. This augment of $\mathrm{pH}(p<0.05)$ may be due the degradation of amino acid by bacteria [59]. 


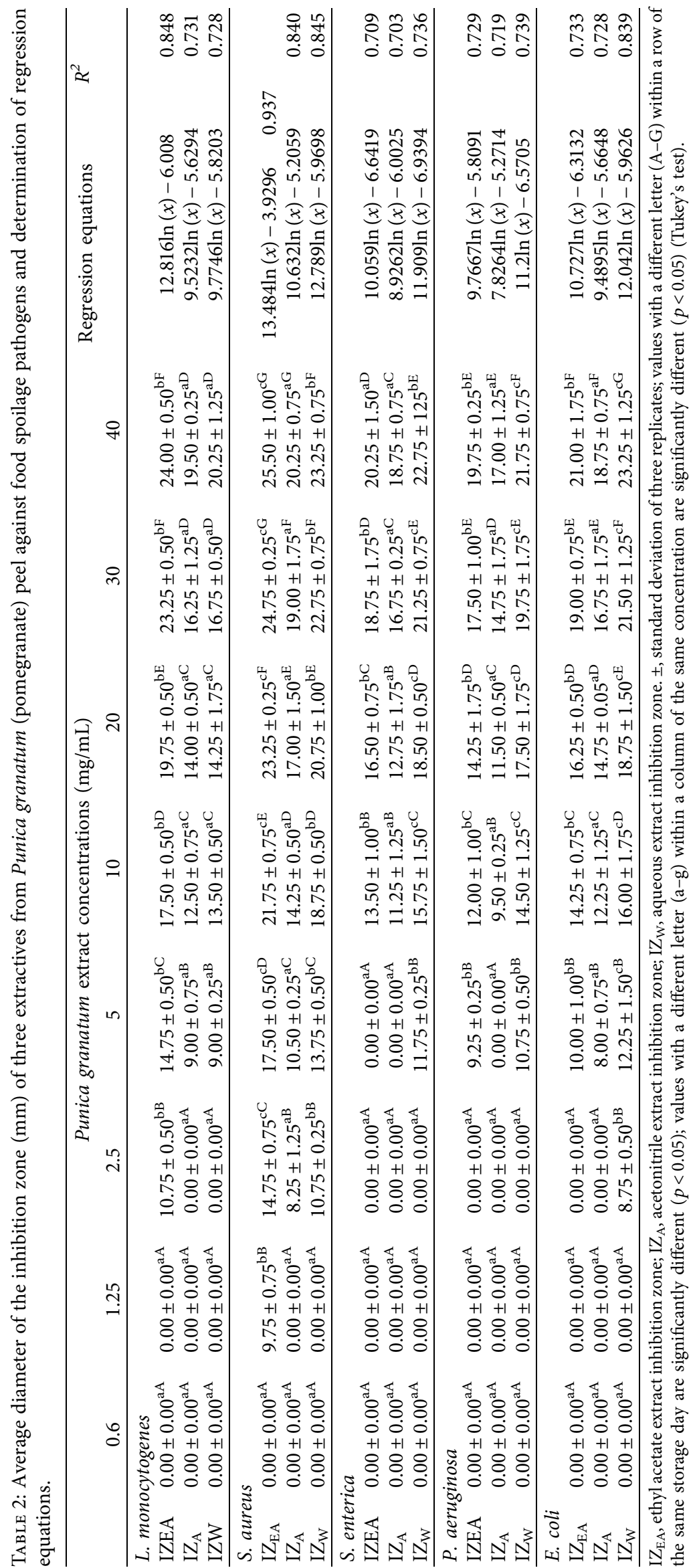


TABle 3: MIC values of three extractives from Punica granatum (pomegranate) peel.

\begin{tabular}{lccc}
\hline \multirow{2}{*}{ Microorganism } & \multicolumn{3}{c}{ MIC $(\mathrm{mg} / \mathrm{mL})$} \\
& Ethyl acetate & Acetonitrile & Water \\
\hline L. monocytogenes & $1.25 \pm 0.00^{\mathrm{a}}$ & $2.50 \pm 0.00^{\mathrm{b}}$ & $2.50 \pm 0.00^{\mathrm{b}}$ \\
S. aureus & $0.60 \pm 0.00^{\mathrm{a}}$ & $1.25 \pm 0.00^{\mathrm{b}}$ & $1.25 \pm 0.00^{\mathrm{b}}$ \\
S. enterica & $5.00 \pm 0.00^{\mathrm{a}}$ & $5.00 \pm 0.00^{\mathrm{a}}$ & $2.50 \pm 0.00^{\mathrm{b}}$ \\
P. aeruginosa & $2.50 \pm 0.00^{\mathrm{a}}$ & $5.00 \pm 0.00^{\mathrm{b}}$ & $2.50 \pm 0.00^{\mathrm{a}}$ \\
E. coli & $2.50 \pm 0.00^{\mathrm{b}}$ & $2.50 \pm 0.00^{\mathrm{b}}$ & $1.25 \pm 0.00^{\mathrm{a}}$ \\
\hline
\end{tabular}

\pm , standard deviation of three replicates; values with a different letter $(\mathrm{a}-\mathrm{d})$ within a column of the same microorganism are significantly different $(p<0.05)$ (Tukey's test).

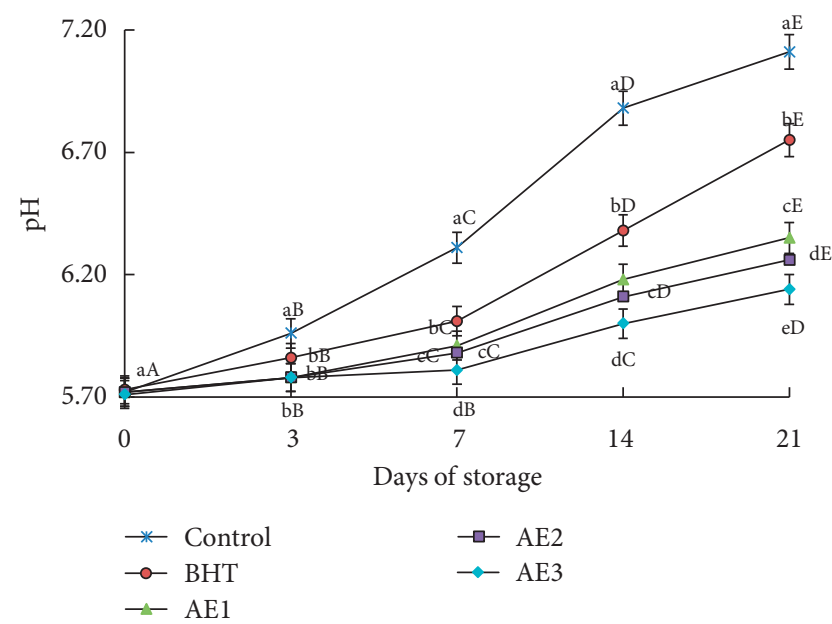

FIGURE 1: Effect of the aqueous pomegranate peel extract on $\mathrm{pH}$ of minced beef meat during storage at $4^{\circ} \mathrm{C}$.

(2) The MetMb Content. The formation rate of MetMb during storage at $4^{\circ} \mathrm{C}$ is shown in Figure 2. During preservation, meat discoloration of meat is frequently recognized due to the myoglobin oxidation in MetMb [60]. For control samples (C), MetMb\% augmented quickly in the first 7 days and extended values above $50.94 \%$, whereas for treated samples (BHT, $A E 1, A E 2$, and $A E 3)$, the $\mathrm{MetMb} \%$ ranged from 32.27 (BHT) to 22.64 (AE3). Limit level of MetMb leading the consumer arise rejection of meat products was determined to $40 \%$ [61]. In our case, this limit value was reached approximately after 14 days of storage for BHT samples. For AE3, MetMb\% values were 37.59, which under the detection limits till the end of storage.

(3) Carbonyl Contents. Aqueous extract-treated raw minced beef meat showed significantly lower $(p<0.05)$ protein carbonyl contents (Figure 3). The protein carbonyl contents displayed that the aqueous extract of pomegranate peel addition could retard protein oxidation in raw minced beef meat. At all sampling days, control samples have significantly higher $(p<0.05)$ amounts of protein carbonyls than treated samples. Initial carbonyl concentrations of control, BHT, 0.1, 0.5, and $1 \%$ AE groups are 0.71, 0.58, 0.51, 0.43, and $0.36 \mathrm{nmol} / \mathrm{mg}$ proteins, respectively. Figure 3 shows, in all samples, an increase of carbonyl levels, which is

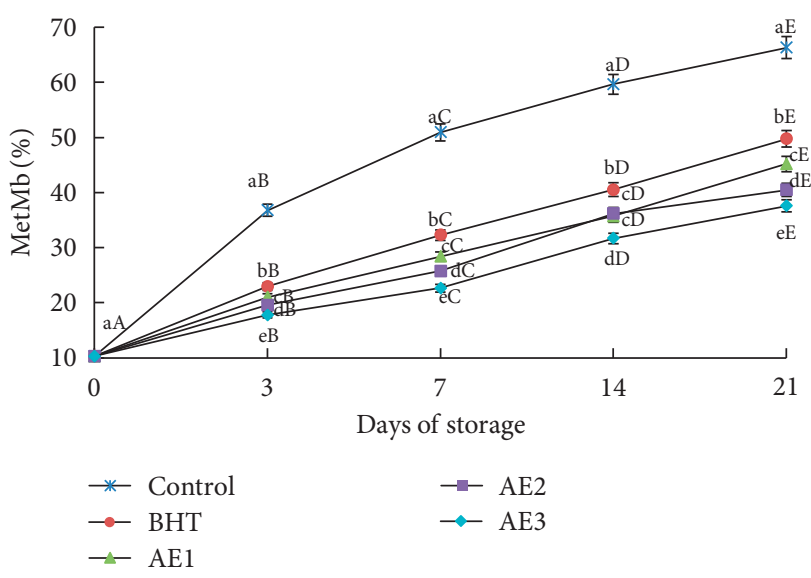

Figure 2: Effect of the aqueous pomegranate peel extract on $\mathrm{MetMb}(\%)$ of minced beef meat during storage at $4^{\circ} \mathrm{C}$.

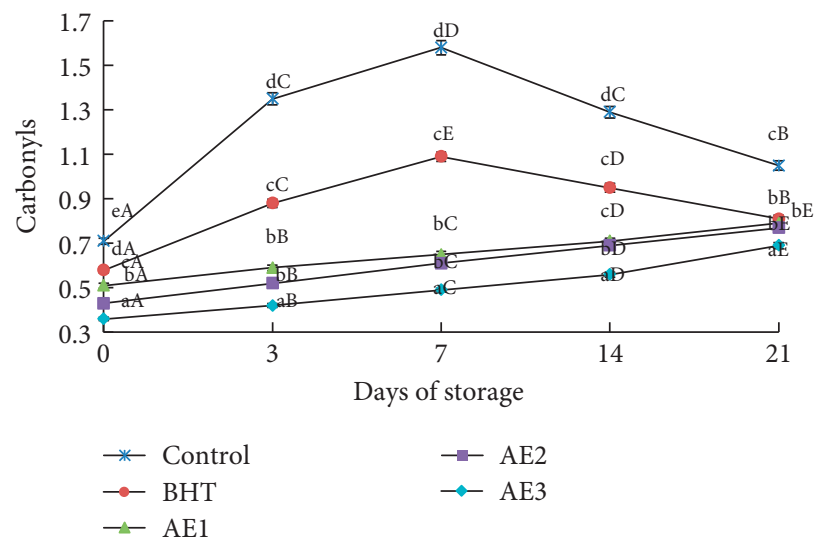

FIGURE 3: Effect of the aqueous pomegranate peel extract on protein carbonyl (nmoles carbonyl/mg protein) of minced beef meat during storage at $4^{\circ} \mathrm{C}$.

demonstrated by the generation of oxidative reactions during 7 days. Until 21 days of storage, AE1-3 and BHT samples showed a significant $(p<0.05)$ effect on final carbonyl concentrations. These results showed that antioxidant sources were able to preventing carbonyl formation. Similarly, the decrease in carbonyl groups was reported for various type of meat [62-64].

(4) Sulphydryl Contents. Storage time resulted in a significant $(p<0.05)$ decrease in sulphydryl contents. As shown in Figure 4 , at 0 day, treated samples with $1 \%$ AE (AE3) presented the lowest \% reduction of sulfhydryl content (16.63\%), followed by the AE2 (21.79\%), AE1 (23.25\%), BHT (32.58\%), and control samples (45.49\%). At the end of storage, the maximum decrease and minimum decrease were found in the control group and AE3, respectively, at 24.11 and $40.39 \mathrm{nmol} / \mathrm{mg}$ proteins. SH occupied an essential role in the enhancement of functional properties of proteins. In this way, the reduction of $\mathrm{SH}$ is associated to the development of disulphide bonds, protein aggregates, and loses its functionality [65]. 


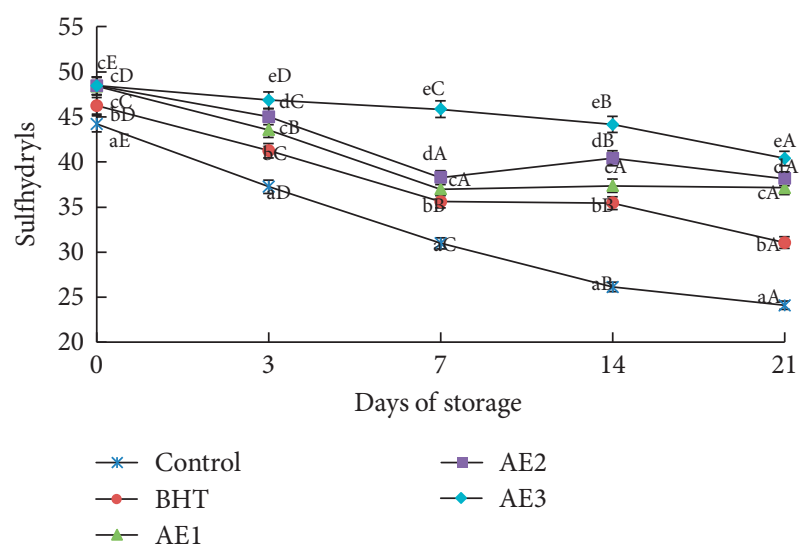

Figure 4: Effect of the aqueous pomegranate peel extract on sulfhydryl (nmoles sulfhydryl/mg protein) of minced beef meat during storage at $4^{\circ} \mathrm{C}$.

(5) Peroxide Value. To be acceptable in fatty foods, PV should not reach the limit of $25 \mathrm{meq}$ peroxide $/ \mathrm{kg}$ of meat $[66,67]$. Figure 5 demonstrates that $\mathrm{AE}$ and storage time (days) have a significant $(p<0.05)$ effect on PV. In fact, at the twenty-first day of storage, lower PV was significantly $(p<0.05)$ investigated in treated AE 3 samples $(14.75 \mathrm{meq}$ peroxide $/ \mathrm{kg}$ of meat) compared to the control $(28.59 \mathrm{meq}$ peroxide $/ \mathrm{kg}$ of meat). The high PV explained the high accumulation of peroxide, which will degrade into ketone and aldehyde [68,69]. AE phenolic compounds properties will possibly participate in the peroxides decomposition leading to the peroxide value decreasing [69].

(6) $C D$. As shown in Figure 6, CD increased significantly $(p<0.05)$ during the first 3 days of storage and then decreased until the end of storage. Remarkably, meat samples containing the aqueous extract (AE1-3) demonstrated CD values significantly $(p<0.05)$ lower than those of control and BHT samples during storage. This decrease could be explained by the fact that the decomposition rate of the hydroperoxides was higher than the formation rate of $\mathrm{CD}$ [70]. Many works reported the lower CD values when different types of meat were treated with plant extracts $[44,71-73]$.

(7) TBARS Value. The reaction between thiobarbituric acid and malonaldehyde (MAD), formed by lipid hydroperoxides decomposition, is employed as the basis for the measurement of secondary oxidation products [74]. Together with peroxide value and conjugated dienes data, a more comprehensive picture on the oxidation of raw minced beef meat can be developed. At the end of the storage period, $\mathrm{AE}$ treatments demonstrated a significant $(p<0.05)$ effect on TBARS values. As shown in Figure 7, TBARS values were superior in control samples (C) than AE-treated samples, with the lowest showed at AE2 and AE3 with $1.79 \pm 0.015$ and $1.56 \pm 0.031 \mathrm{mg}$ of malonaldehyde $/ \mathrm{kg}$ of sample, respectively. These latter levels respected the detection limit (2 mg MDA $/ \mathrm{kg}$ ) recommended by Botsoglou et al. [71]. Equally, a similar positive effect of sage extracts $[75,76]$,

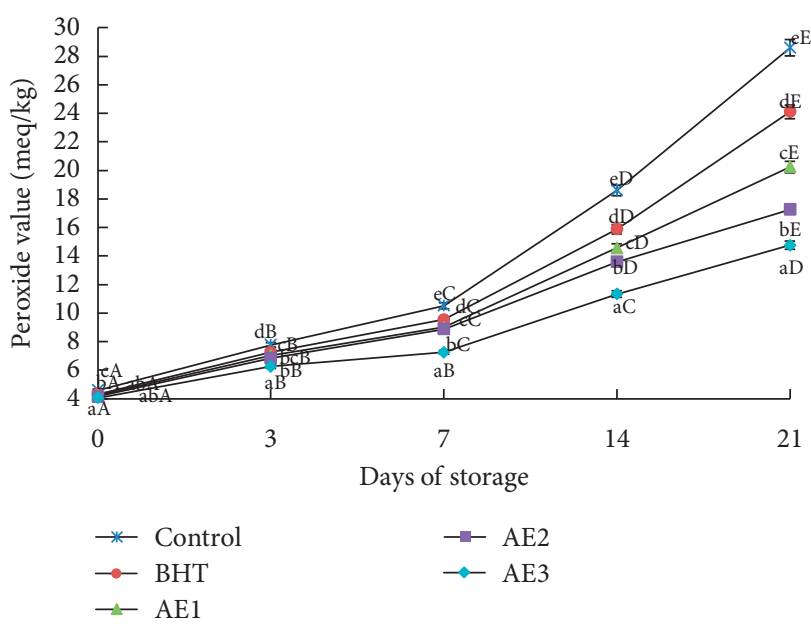

Figure 5: Effect of the aqueous pomegranate peel extract on peroxide values (meq peroxide $/ \mathrm{kg}$ of meat) of minced beef meat during storage at $4^{\circ} \mathrm{C}$.

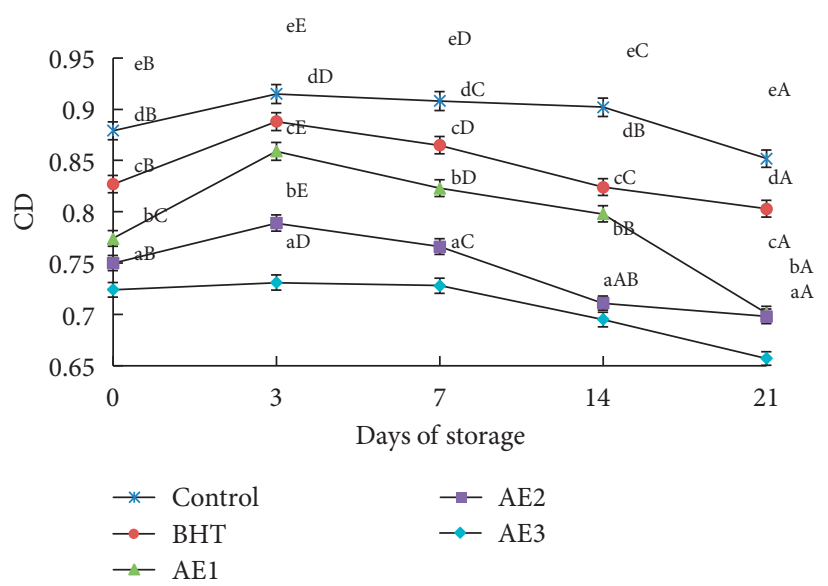

Figure 6: Effect of the aqueous pomegranate peel extract on conjugated dienes ( $\mu \mathrm{mol} / \mathrm{mg}$ of meat) of minced beef meat during storage at $4^{\circ} \mathrm{C}$.

curry, and mint leaf extracts [77] in pork meat systems was found.

3.4.2. Microbiological Evaluation. After 14 days of storage, APC showed a rapid increase in control sample reaching the minimal spoilage level $\left(5.10^{6} \mathrm{CFU} / \mathrm{g} \sim \log _{10} 6.7 \mathrm{CFU} / \mathrm{g}\right)[78]$. In the first day of storage (day 0) (Figure 8), APC and TPC of different samples was above $2.35 \mathrm{log} \mathrm{CFU} / \mathrm{g}$. In the twentyfirst day, APC of AE1, AE2, and AE3 samples was gradually increased $(p<0.05)$ and reached $7.18,6.59$, and 6.23 $\log \mathrm{CFU} / \mathrm{g}$, respectively. As well for TPC, the levels were AE1 (5.84 $\log \mathrm{CFU} / \mathrm{g}), \mathrm{AE} 2$ (5.71 $\log \mathrm{CFU} / \mathrm{g}$ ), and AE3 (5.11 $\log$ CFU/g). It should be mentioned that limit levels of both APC and TPC leading raw minced beef meat unsuitable for use was $\log 6.7 \mathrm{CFU} / \mathrm{g}$ [79].

Comparable to our results, preceding reports verified that the APC of meat products were considerably reduced by 


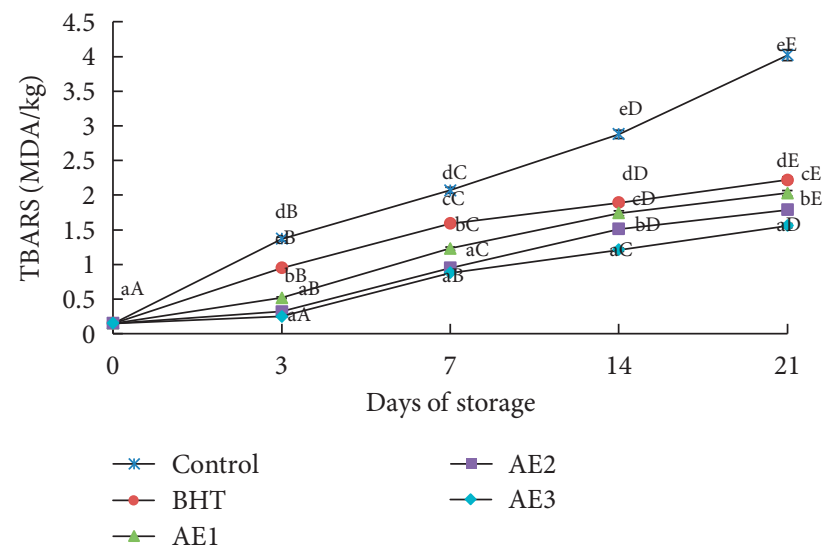

FIGURE 7: Effect of the aqueous pomegranate peel extract on TBARS (mg MDA/kg meat) of minced beef meat during storage at $4^{\circ} \mathrm{C}$.

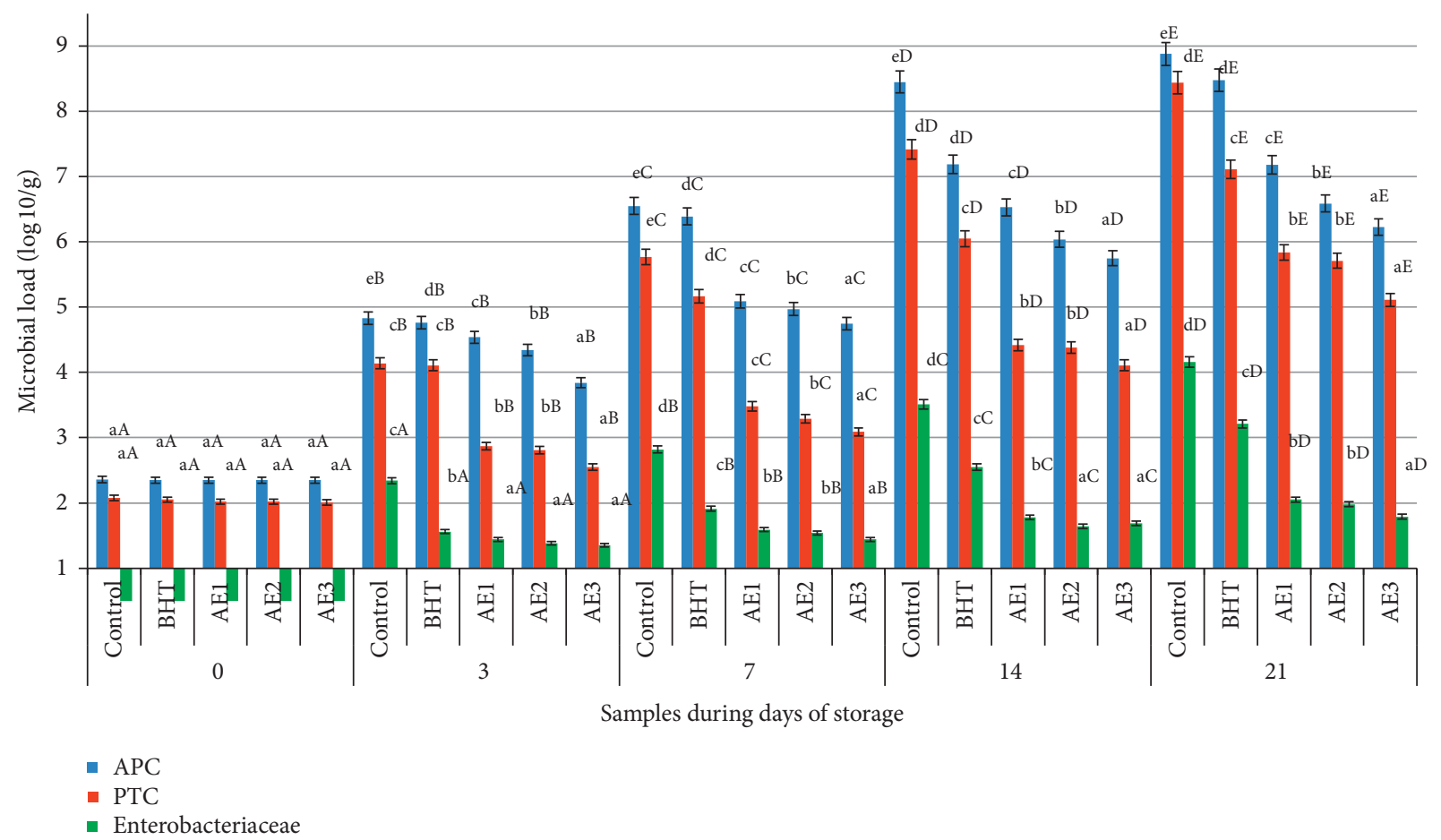

FIGURE 8: Effect of the aqueous pomegranate peel extract on the microbial load of aerobic plate count (APC), psychrotrophic count (PTC), and Enterobacteriaceae count of raw minced meat beef during storage at $4^{\circ} \mathrm{C}$.

the addition of Moringa leaves in beef burgers [80] and herbal chicken sausage [81] kept at $4^{\circ} \mathrm{C}$ for five weeks. Besides, Hawashin et al. [82] stated that destoned olive cake powder tardy bacterial growth in beef patties during 14 days.

3.4.3. Sensory Evaluation. During the storage time, all the sensory characteristics were significantly $(p<0.05)$ decreased, whereas the treated samples exposed exceptional stability until 14 days due to the fact that the limit of rejection is 5 . As shown in Table 4, the overall acceptability of minced beef meat treated with BHT, AE1, AE2, and AE3 was acceptable until 14 days $(p<0.05)$ but unacceptable for untreated samples (C) from day 7 $(p<0.05)$. A dissimilar trend has been reported by Hawashin et al. [82], Al-Juhaimi et al. [80], and Muthukumar et al. [83] who found an insignificant decrease or changes in sensory attributes.

\subsection{Linear Regression Analysis}

3.5.1. Relationship between Overall Acceptability and Physicochemical Parameters. In the beginning of storage at $4^{\circ} \mathrm{C}, \mathrm{pH}$ and sulfhydryl contents showed that a positive effect on the overall acceptability $(\mathrm{OA})$ with regression coefficients was higher in treated samples compared to control (Table 5). In day 3 , it should be noted that levels higher than 6.25 meq peroxide $/ \mathrm{kg}$ of 
TABLE 4: Effect of the aqueous pomegranate peel extract on color, appearance, odor, and overall acceptability of raw minced meat beef stored at $4^{\circ} \mathrm{C}$.

\begin{tabular}{|c|c|c|c|c|c|}
\hline & \multicolumn{5}{|c|}{ Days of storage at $4^{\circ} \mathrm{C}$} \\
\hline & 0 & 3 & 7 & 14 & 21 \\
\hline \multicolumn{6}{|l|}{ Color } \\
\hline Control & $6.33 \pm 0.25^{\mathrm{aE}}$ & $6.15 \pm 0.15^{\mathrm{aD}}$ & $5.55 \pm 0.25^{\mathrm{aC}}$ & $3.25 \pm 0.15^{\mathrm{aB}}$ & $2.22 \pm 0.02^{\mathrm{aA}}$ \\
\hline $\mathrm{BHT}$ & $6.51 \pm 0.23^{\mathrm{bD}}$ & $6.55 \pm 0.17^{\mathrm{bD}}$ & $6.15 \pm 0.25^{\mathrm{bC}}$ & $5.37 \pm 0.11^{\mathrm{bB}}$ & $3.75 \pm 0.04^{\mathrm{bA}}$ \\
\hline AE1 & $6.51 \pm 0.18^{\mathrm{bD}}$ & $6.55 \pm 0.10^{\mathrm{bD}}$ & $6.33 \pm 0.14^{\mathrm{bcC}}$ & $5.87 \pm 0.16^{\mathrm{cB}}$ & $3.83 \pm 0.08^{\mathrm{bA}}$ \\
\hline AE2 & $6.83 \pm 0.11^{\mathrm{cD}}$ & $6.61 \pm 0.28^{\mathrm{bC}}$ & $6.55 \pm 0.21^{\mathrm{cC}}$ & $5.93 \pm 0.22^{\mathrm{cB}}$ & $3.83 \pm 0.09^{\mathrm{bA}}$ \\
\hline AE3 & $6.92 \pm 0.22^{\mathrm{dD}}$ & $6.83 \pm 0.25^{\mathrm{cCD}}$ & $6.77 \pm 0.20^{\mathrm{dC}}$ & $6.12 \pm 0.18^{\mathrm{dB}}$ & $4.25 \pm 0.14^{\mathrm{cA}}$ \\
\hline \multicolumn{6}{|c|}{ Appearance } \\
\hline Control & $6.83 \pm 0.15^{\mathrm{aE}}$ & $6.25 \pm 0.14^{\mathrm{aD}}$ & $5.11 \pm 0.11^{\mathrm{aC}}$ & $3.25 \pm 0.25^{\mathrm{aB}}$ & $2.83 \pm 0.02^{\mathrm{aA}}$ \\
\hline $\mathrm{BHT}$ & $6.92 \pm 0.10^{\mathrm{aD}}$ & $6.33 \pm 0.13^{\mathrm{aC}}$ & $6.33 \pm 0.19^{\mathrm{bC}}$ & $5.25 \pm 0.24^{\mathrm{bB}}$ & $3.11 \pm 0.04^{\mathrm{bA}}$ \\
\hline AE1 & $6.92 \pm 0.20^{\mathrm{aE}}$ & $6.50 \pm 0.19^{\mathrm{bD}}$ & $6.33 \pm 0.28^{\mathrm{bC}}$ & $6.00 \pm 0.11^{\mathrm{cB}}$ & $3.11 \pm 0.09^{\mathrm{bA}}$ \\
\hline $\mathrm{AE} 2$ & $7.50 \pm 0.19^{\mathrm{bE}}$ & $6.71 \pm 0.12^{\mathrm{cD}}$ & $6.50 \pm 0.25^{\mathrm{cC}}$ & $6.00 \pm 0.19^{\mathrm{cB}}$ & $3.50 \pm 0.08^{\mathrm{cA}}$ \\
\hline AE3 & $7.50 \pm 0.15^{\mathrm{bE}}$ & $6.83 \pm 0.23^{\mathrm{dD}}$ & $6.66 \pm 0.24^{\mathrm{dC}}$ & $6.33 \pm 0.11^{\mathrm{dB}}$ & $3.83 \pm 0.05^{\mathrm{dA}}$ \\
\hline \multicolumn{6}{|l|}{ Odor } \\
\hline Control & $6.17 \pm 0.27^{\mathrm{aE}}$ & $6.00 \pm 0.22^{\mathrm{aD}}$ & $5.78 \pm 0.18^{\mathrm{aC}}$ & $3.55 \pm 0.09^{\mathrm{aB}}$ & $2.22 \pm 0.02^{\mathrm{aA}}$ \\
\hline BHT & $6.25 \pm 0.20^{\mathrm{abE}}$ & $6.00 \pm 0.19^{\mathrm{aD}}$ & $5.83 \pm 0.18^{\mathrm{aC}}$ & $5.25 \pm 0.22^{\mathrm{bB}}$ & $2.75 \pm 0.08^{\mathrm{bA}}$ \\
\hline $\mathrm{AE} 1$ & $6.33 \pm 0.25^{\mathrm{bD}}$ & $6.17 \pm 0.22^{\mathrm{bCD}}$ & $6.00 \pm 0.22^{\mathrm{bC}}$ & $5.37 \pm 0.22^{\mathrm{bB}}$ & $3.25 \pm 0.02^{\mathrm{cA}}$ \\
\hline $\mathrm{AE} 2$ & $6.66 \pm 0.22^{\mathrm{cC}}$ & $6.50 \pm 0.16^{\mathrm{cC}}$ & $6.50 \pm 0.29^{\mathrm{cC}}$ & $5.62 \pm 0.19^{\mathrm{cB}}$ & $3.50 \pm 0.09^{\mathrm{dA}}$ \\
\hline AE3 & $6.83 \pm 0.19^{\mathrm{dD}}$ & $6.75 \pm 0.15^{\mathrm{dCD}}$ & $6.66 \pm 0.11^{\mathrm{dC}}$ & $5.87 \pm 0.15^{\mathrm{dB}}$ & $3.75 \pm 0.07^{\mathrm{eA}}$ \\
\hline \multicolumn{6}{|c|}{ Overall acceptability } \\
\hline Control & $6.50 \pm 0.22^{\mathrm{aE}}$ & $6.25 \pm 0.25^{\mathrm{aD}}$ & $5.83 \pm 0.19^{\mathrm{aC}}$ & $3.37 \pm 0.15^{\mathrm{aB}}$ & $2.50 \pm 0.05^{\mathrm{aA}}$ \\
\hline BHT & $6.50 \pm 0.19^{\mathrm{aE}}$ & $6.33 \pm 0.26^{\mathrm{aD}}$ & $6.00 \pm 0.17^{\mathrm{bC}}$ & $5.75 \pm 0.25^{\mathrm{bB}}$ & $2.75 \pm 0.02^{\mathrm{bA}}$ \\
\hline $\mathrm{AE} 1$ & $6.66 \pm 0.19^{\mathrm{bD}}$ & $6.33 \pm 0.28^{\mathrm{aC}}$ & $6.17 \pm 0.10^{\mathrm{cB}}$ & $6.12 \pm 0.11^{\mathrm{cB}}$ & $2.83 \pm 0.08^{\mathrm{bA}}$ \\
\hline AE2 & $6.66 \pm 0.15^{\mathrm{bC}}$ & $6.66 \pm 0.22^{\mathrm{bC}}$ & $6.33 \pm 0.11^{\mathrm{dB}}$ & $6.25 \pm 0.27^{\mathrm{dB}}$ & $3.00 \pm 0.07^{\mathrm{cA}}$ \\
\hline AE3 & $6.77 \pm 0.21^{\mathrm{cC}}$ & $6.71 \pm 0.27^{\mathrm{bC}}$ & $6.50 \pm 0.18^{\mathrm{eB}}$ & $6.50 \pm 0.22^{\mathrm{eB}}$ & $3.33 \pm 0.04^{\mathrm{dA}}$ \\
\hline
\end{tabular}

\pm , standard deviation of three replicates; values with a different letter (a-e) within a row of the same storage day are significantly different $(p<0.05)$ (Tukey's test). Values with a different letter (A-E) within a column of the same concentration are significantly different $(p<0.05)$ (Tukey's test).

meat (PV of AE3) and $0.731 \mu \mathrm{mol} / \mathrm{mg}$ of meat (CD of AE3), respectively, for $\mathrm{PV}$ and $\mathrm{CD}$ (Table 5) affected negatively the $\mathrm{OA}$ of the raw minced beef meat, whereas predicted OA was not influenced by MetMb up to $36.76 \%$ (MetMb of control samples). Equally, the loss of sulphydryl groups of treated samples AE3 (3.302\%), AE2 (7.079\%), and AE1 (9.977\%) showed a strong positive correlation, respectively, with $\mathrm{OA}_{3}, \mathrm{OA}_{2}$, and $\mathrm{OA}_{1}$, while a percentage of $15 \%$ of the loss of sulphydryl groups (control) had a negative influence on the $\mathrm{OA}_{\mathrm{C}}(-0.014)$ (Table 5).

A negative effect of protein oxidation parameters on the overall acceptability was distinguished in control samples after 7 days of storage. This latter was probably explained by an endogenous reducing enzyme's action in MetMb [24] and a higher degree of protein oxidation in case of lower sulfhydryl [84]. Equally, secondary lipid oxidation products (TBARS) correlated negatively with the $\mathrm{OA}_{\mathrm{C}}$. Smaoui et al. [64] have reported that both $\mathrm{CD}$ and PV influence TBARS: these relationships were established through Bayesian networks and Pearson coefficients correlation. In fact, after 7 days of storage, primary (PV and CD) and secondary (TBARS) lipid oxidation products of control sample acted a negative correlation on $\mathrm{OA}_{\mathrm{C}}$. For BHT samples, loss of sulphydryl groups at $23.048 \%$ contributed a negative effect on $\mathrm{OA}_{\mathrm{BHT}}$ (Table 5). Furthermore, for AE1, the sulphydryl groups had a negative effect on $\mathrm{OAC}_{\mathrm{AE} 1}$, while for $\mathrm{AE} 1$ and AE2, the loss up to $16.594 \%$ (loss of sulphydryl groups of AE2) acted a positive effect on OA. After 14 days, all treated samples except AE3 presented a negative effect of TBARS. Thereby, predicted OA of AE3 appeared to be the most remarkable (Table 5) and could be presented as follows:

$$
\mathrm{OA}_{\mathrm{AE} 3}=2.947+0.314 \times \mathrm{pH}+0.352 \times \mathrm{MetMb}+0.122 \times \mathrm{Sulph}-0.114 \times \mathrm{PV}-1.128 \times \mathrm{CD}+0.127 \times \mathrm{TBARS} .
$$

3.5.2. Relationship between Overall Acceptability and Sensory Parameters. In day 0 , for all samples, a positive effect of color was shown on the predicted overall acceptability (Table 6). The predicted overall acceptability was found to be the same for control and BHT samples, while the treatment by the aqueous extract improved significantly the color compared to control and $\mathrm{BHT}$ samples. In fact, $\mathrm{OA}_{\mathrm{AE} 3}$ was 1.7 times higher than $\mathrm{OA}_{\mathrm{C}}$ and $\mathrm{OA}_{\mathrm{BHT}}$ (Table 6). After 3 days, compared to control and BHT samples, we noticed that the ethanolic extract significantly improved the color and the odor. Like the $7^{\text {th }}$ day of storage at $4^{\circ} \mathrm{C}$, color and odor parameters remained the same (Table 6). The aqueous 


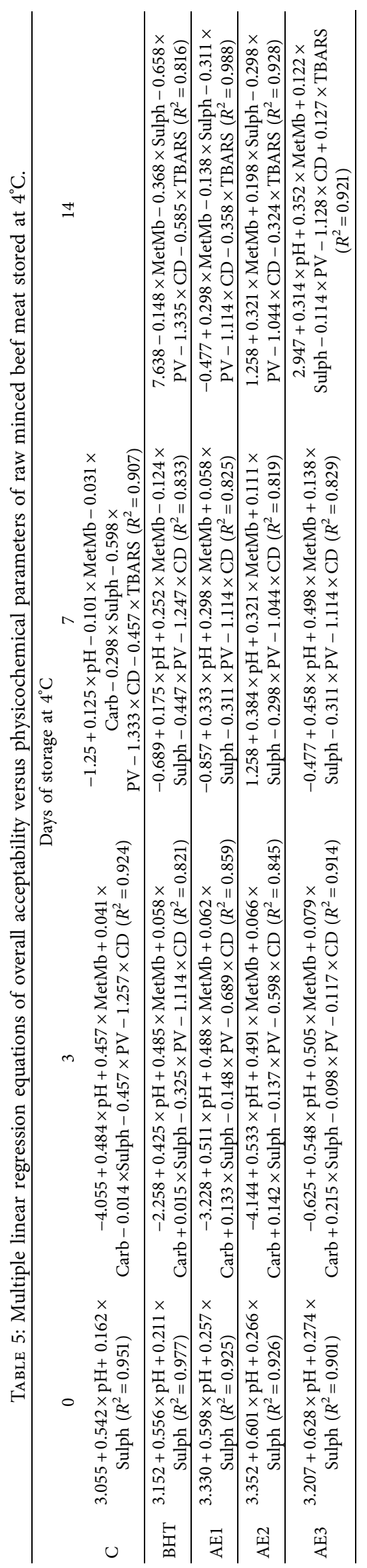


TABLE 6: Multiple linear regression equations of overall acceptability versus sensorial parameters of raw minced beef meat stored at $4^{\circ} \mathrm{C}$.

\begin{tabular}{ccccc}
\hline \multicolumn{5}{c}{ Days of storage at $4^{\circ} \mathrm{C}$} \\
\hline C & $\begin{array}{c}3.129+0.516 \times \text { color } \\
\left(R^{2}=0.859\right)\end{array}$ & $-4.258+0.384 \times$ color $\left(R^{2}=0.958\right)$ & $-11.289+0.125 \times$ color $\left(R^{2}=0.901\right)$ & 14 \\
\hline BHT & $\begin{array}{c}4.328+0.514 \times \text { color } \\
\left(R^{2}=0.856\right)\end{array}$ & $-2.521+0.488 \times$ color $\left(R^{2}=0.955\right)$ & $-3.729+0.375 \times$ color $\left(R^{2}=0.914\right)$ & $\begin{array}{c}9.355-0.149 \times \text { appearance }+0.248 \times \text { color } \\
\left(R^{2}=0.918\right)\end{array}$ \\
\hline AE1 & $\begin{array}{c}3.005+0.537 \times \text { color } \\
\left(R^{2}=0.866\right)\end{array}$ & $\begin{array}{c}1.29+0.468 \times \text { color }+0.801 \times \text { odor } \\
\left(R^{2}=0.914\right)\end{array}$ & $\begin{array}{c}-6.929+0.414 \times \text { color }+0.521 \times \text { odor } \\
\left(R^{2}=0.904\right)\end{array}$ & $\begin{array}{c}5.267+0.114 \times \text { color }+0.324 \times \text { odor } \\
\left(R^{2}=0.921\right)\end{array}$ \\
\hline AE2 & $\begin{array}{c}-2.658+0.667 \times \text { color } \\
\left(R^{2}=0.824\right)\end{array}$ & $\begin{array}{c}4.119+0.501 \times \text { color }+1.297 \times \text { odor } \\
\left(R^{2}=0.927\right)\end{array}$ & $\begin{array}{c}-8.524+0.487 \times \text { color }+0.787 \times \text { odor } \\
\left(R^{2}=0.864\right)\end{array}$ & $\begin{array}{c}-1.987+0.333 \times \text { color }+0.597 \times \text { odor } \\
\left(R^{2}=0.847\right)\end{array}$ \\
\hline AE3 & $\begin{array}{c}1.257+0.897 \times \text { color } \\
\left(R^{2}=0.836\right)\end{array}$ & $\begin{array}{c}7.984+0.748 \times \text { color }+1.547 \times \text { odor } \\
\left(R^{2}=0.911\right)\end{array}$ & $\begin{array}{c}7.598+0.657 \times \text { color }+1.247 \times \text { odor } \\
\left(R^{2}=0.887\right)\end{array}$ & $\begin{array}{c}9.587+0.488 \times \text { color }+1.107 \times \text { odor } \\
\left(R^{2}=0.888\right)\end{array}$ \\
\hline
\end{tabular}

extract at $1 \%$ (AE3) application after 7 days of storage enhanced significantly the color and odor (Table 6). The odor of $\mathrm{OA}_{\mathrm{AE} 3}$ was $1.584(1.247 / 0.787)$ and $2.393(1.247 /$ $0.521)$ times higher than the odor of $\mathrm{AE} 1$ and $\mathrm{AE} 2$, respectively. After 14 days of storage at $4^{\circ} \mathrm{C}$, the predicted OA for AE3 was directly correlated to the increase of color and odor attributes. Similarly, the regression coefficients of these two parameters remained higher for AE3 compared with that for AE1 and AE2 (Table 6). Overall, these findings showed the strongest preservative effect of the water extract at $1 \%(\mathrm{AE} 3)$.

\section{Conclusions}

Pomegranate peels were extracted by three different solvents (ethyl acetate, acetonitrile, and water) and used to study their phytochemical content, antioxidant activity, and antibacterial potential against foodborne pathogenic bacteria. In our study, the ethyl acetate extract presented the most elevated content of polyphenols, flavonoids, DPPH, and ABTS inhibition followed by the aqueous extract. Equally, the three extracts demonstrated notable antibacterial activities against all analyzed bacterial strains.

The minced beef meat susceptible to spoilage and pathogenic bacteria, and lipid and protein oxidation, has limited shelf life. In this regard, in a second part of the present work, we demonstrated the big effect on microbiological, physicochemical, and sensory analyses in minced beef meat carried by the aqueous extract of pomegranate peel.

Oxidation stability of proteins, lipids, and sensory changes were well improved by the addition of $\mathrm{AE}$ at $0.5-1 \%$, while using BHT at legal limit sowed less effectiveness. We have investigated two overall acceptability relationships, one with physicochemical change and other with sensory parameters. As a potential source of phenolic compounds, the AE3 extract could be effectively considered as a promising tool and secured method, used soon in meat products preservation.

\section{Data Availability}

The data used to support the findings of this study are available from the corresponding author upon request.

\section{Conflicts of Interest}

The authors declare that there are no conflicts of interest.

\section{Authors' Contributions}

Mariam Fourati and Slim Smaoui contributed equally to this work.

\section{Acknowledgments}

This research was funded by the Tunisian Ministry of Higher Education and Scientific Research (program contract 2015-2018 of the Laboratory of Microorganisms and Biomolecules of the Center of Biotechnology of Sfax, Tunisia).

\section{References}

[1] K. Zerabruk, N. Retta, D. Muleta, and A. T. Tefera, “Assessment of microbiological safety and quality of minced meat and meat contact surfaces in selected butcher shops of Addis Ababa, Ethiopia," Journal of Food Quality, vol. 2019, Article ID 3902690, 7 pages, 2019.

[2] N. Lee, H. S. Kwak, J. Y. Joo, J. Kang, and Y. Lee, "Effects of partial replacement of pork meat with chicken or duck meat on the texture, flavor, and consumer acceptance of sausage," Journal of Food Quality, vol. 2018, Article ID 6972848, 7 pages, 2018.

[3] A. Augustyńska-Prejsnar, M. Ormian, and Z. Sokołowicz, "Physicochemical and sensory properties of broiler chicken breast meat stored frozen and thawed using various methods," Journal of Food Quality, vol. 2018, Article ID 6754070, 9 pages, 2018.

[4] M. Zareian, T. Tybussek, P. Silcock, P. Bremer, J. Beauchamp, and N. Böhner, "Interrelationship among myoglobin forms, lipid oxidation and protein carbonyls in minced pork packaged under modified atmosphere," Food Packaging and Shelf Life, vol. 20, Article ID 100311, 2019.

[5] M. Fourati, S. Smaoui, H. Ben Hlima et al., "Synchronised interrelationship between lipid/protein oxidation analysis and sensory attributes in refrigerated minced beef meat formulated with Punica granatum peel extract," International Journal of Food Science \& Technology, vol. 55, no. 3, pp. 1080-1087, 2020.

[6] S. Smaoui, H. Ben Hlima, A. Mtibaa-Chakchouk et al., "Pomegranate peel as phenolic compounds source: advanced analytical strategies and practical use in meat products," Meat Science, vol. 158, Article ID 107914, 2019.

[7] S. Smaoui, A. B. Hsouna, A. Lahmar et al., "Bio-preservative effect of the essential oil of the endemic Mentha piperita used alone and in combination with BacTN6 ${ }_{35}$ in stored minced beef meat," Meat Science, vol. 117, pp. 196-204, 2016. 
[8] L. Bouarab-Chibane, B. Ouled-Bouhedda, L. Leonard et al., "Preservation of fresh ground beef patties using plant extracts combined with a modified atmosphere packaging," European Food Research and Technology, vol. 243, no. 11, pp. 1997-2009, 2017.

[9] R. Prommachart, T. S. Belem, S. Uriyapongson, P. RayasDuarte, J. Uriyapongson, and R. Ramanathan, "The effect of black rice water extract on surface color, lipid oxidation, microbial growth, and antioxidant activity of beef patties during chilled storage," Meat Science, vol. 164, Article ID 108091, 2020.

[10] T. T. T. Tran, N. M. N. Ton, T. T. Nguyen et al., “Application of natural antioxidant extract from guava leaves (Psidium guajava L.) in fresh pork sausage," Meat Science, vol. 165, Article ID 108106, 2020.

[11] P. E. S. Munekata, G. Rocchetti, M. Pateiro, L. Lucini, R. Domínguez, and J. M. Lorenzo, "Addition of plant extracts to meat and meat products to extend shelf-life and healthpromoting attributes: an overview," Current Opinion in Food Science, vol. 31, pp. 81-87, 2020.

[12] X.-J. Fan, S.-Z. Liu, H.-H. Li et al., "Effects of Portulaca oleracea L. extract on lipid oxidation and color of pork meat during refrigerated storage," Meat Science, vol. 147, pp. 82-90, 2019.

[13] A. P. Koné, Y. Desjardins, A. Gosselin, D. Cinq-Mars, F. Guay, and L. Saucier, "Plant extracts and essential oil product as feed additives to control rabbit meat microbial quality," Meat Science, vol. 150, pp. 111-121, 2019.

[14] H. Ben Hlima, T. Bohli, M. Kraiem et al., "Combined effect of Spirulina platensis and Punica granatum peel extacts: phytochemical content and antiphytophatogenic activity," $A p$ plied Sciences, vol. 9, no. 24, p. 5475, 2019.

[15] A. Alirezalu, N. Ahmadi, P. Salehi et al., "Physicochemical characterization, antioxidant activity, and phenolic compounds of Hawthorn (Crataegus spp.) fruits species for potential use in food applications," Foods, vol. 9, no. 4, p. 436, 2020.

[16] S. S. Turgut, A. Soyer, and F. Işıkçı, "Effect of pomegranate peel extract on lipid and protein oxidation in beef meatballs during refrigerated storage," Meat Science, vol. 116, pp. 126132, 2016.

[17] Z. Emam-Djomeh, A. Moghaddam, and S. A. Yasini Ardakani, "Antimicrobial activity of pomegranate (Punica granatum L.) peel extract, physical, mechanical, barrier and antimicrobial properties of pomegranate peel extract-incorporated sodium caseinate film and application in packaging for ground beef," Packaging Technology and Science, vol. 28, no. 10, pp. 869-881, 2015.

[18] B. A. Wafa, M. Makni, S. Ammar et al., "Antimicrobial effect of the Tunisian Nana variety Punica granatum L. extracts against Salmonella enterica (serovars Kentucky and Enteritidis) isolated from chicken meat and phenolic composition of its peel extract," International Journal of Food Microbiology, vol. 241, pp. 123-131, 2017.

[19] S. Devatkal, R. Anurag, B. Jaganath, and S. Rao, "Microstructure, microbial profile and quality characteristics of highpressure-treated chicken nuggets," Food Science and Technology International, vol. 21, no. 7, pp. 481-491, 2015.

[20] S. R. Kanatt, R. Chander, and A. Sharma, "Antioxidant and antimicrobial activity of pomegranate peel extract improves the shelf life of chicken products," International Journal of Food Science \& Technology, vol. 45, no. 2, pp. 216-222, 2010.

[21] B. M. Naveena, A. R. Sen, S. Vaithiyanathan, Y. Babji, and N. Kondaiah, "Comparative efficacy of pomegranate juice, pomegranate rind powder extract and BHT as antioxidants in cooked chicken patties," Meat Science, vol. 80, no. 4, pp. 1304-1308, 2008.

[22] S. K. Devatkal, P. Thorat, and M. Manjunatha, "Effect of vacuum packaging and pomegranate peel extract on quality aspects of ground goat meat and nuggets," Journal of Food Science and Technology, vol. 51, no. 10, pp. 2685-2691, 2014.

[23] S. Hu, H. Wang, W. Han, Y. Ma, Z. Shao, and L. Li, "Development of double-layer active films containing pomegranate peel extract for the application of pork packaging," Journal of Food Process Engineering, vol. 40, no. 2, Article ID e12388, 2017.

[24] B. Shan, Y.-Z. Cai, J. D. Brooks, and H. Corke, "Antibacterial and antioxidant effects of five spice and herb extracts as natural preservatives of raw pork," Journal of the Science of Food and Agriculture, vol. 89, no. 11, pp. 1879-1885, 2009.

[25] W. Elfalleh, N. Nasri, N. Marzougui et al., "Physico-chemical properties and DPPH-ABTS scavenging activity of some local pomegranate (Punica granatum) ecotypes," International Journal of Food Sciences and Nutrition, vol. 60, no. 2, pp. 197-210, 2009.

[26] W. Elfalleh, N. Tlili, N. Nasri et al., "Antioxidant capacities of phenolic compounds and tocopherols from Tunisian pomegranate (Punica granatum) fruits," Journal of Food Science, vol. 76, no. 5, pp. C707-C713, 2011.

[27] C. El Kar, A. Ferchichi, F. Attia, and J. Bouajila, "Pomegranate (Punica granatum) juices: chemical composition, micronutrient cations, and antioxidant capacity," Journal of Food Science, vol. 76, no. 6, pp. C795-C800, 2011.

[28] J. Bekir, M. Mars, P. Vicendo, A. Fterrich, and J. Bouajila, "Chemical composition and antioxidant, anti-inflammatory, and antiproliferation activities of pomegranate (Punica granatum) flowers," Journal of Medicinal Food, vol. 16, no. 6, pp. 544-550, 2013.

[29] V. L. Singleton and J. A. Rossi, "Colorimetry of total phenolics with phosphomolybdic phosphotungstic acid reagents," American Journal of Enology and Viticulture, vol. 16, pp. 144-158, 1965.

[30] C. Quettier-Deleu, B. Gressier, J. Vasseur et al., "Phenolic compounds and antioxidant activities of buckwheat (Fagopyrum esculentum Moench) hulls and flour," Journal of Ethnopharmacology, vol. 72, no. 1-2, pp. 35-42, 2000.

[31] P. Bersuder, M. Hole, and G. Smith, "Antioxidants from a heated histidine-glucose model system. I: investigation of the antioxidant role of histidine and isolation of antioxidants by high-performance liquid chromatography," Journal of the American Oil Chemists' Society, vol. 75, no. 2, pp. 181-187, 1998.

[32] R. Re, N. Pellegrini, A. Proteggente, A. Pannala, M. Yang, and C. Rice-Evans, "Antioxidant activity applying an improved ABTS radical cation decolorization assay," Free Radical Biology and Medicine, vol. 26, no. 9-10, pp. 1231-1237, 1999.

[33] K. Güven, E. Yücel, and F. Cetintaş, "Antimicrobial activities of fruits of crataegus and pyrus species," Pharmaceutical Biology, vol. 44, no. 2, pp. 79-83, 2006.

[34] M. Gulluce, F. Sahin, M. Sokmen et al., "Antimicrobial and antioxidant properties of the essential oils and methanol extract from Mentha longifolia L. ssp. Longifolia," Food Chemistry, vol. 103, no. 4, pp. 1449-1456, 2007.

[35] O. K. Topuz, P. Yerlikaya, İ. Uçak, B. Gümüş, H. A. Büyükbenli, and N. Gökoğlu, "Influence of pomegranate peel (Punica granatum) extract on lipid oxidation in anchovy fish oil under heat accelerated conditions," Journal of Food Science and Technology, vol. 52, no. 1, pp. 625-632, 2015. 
[36] ISO, Microbiology of the Food Chain-Horizontal Method for the Enumeration of Microorganisms. Part 2: Colony Count at 30 Degrees C by the Surface Plating Technique (ISO 4833-2), International Organization for Standardization, Geneva, Switzerland, 2013.

[37] ISO, Microbiology of Food and Animal Feeding Stuffs-Horizontal Method for the Enumeration of Psychrotropic Microorganisms (ISO 17410), International Organization for Standardization, Geneva, Switzerland, 2001.

[38] ISO, Microbiology of Food and Animal Feeding Stuffs-Horizontal Methods for the Detection and Enumeration of Enterobacteriaceae. Part 2: Colony-count method (ISO 21528-2), International Organization for Standardization, Geneva, Switzerland, 2004.

[39] G. Özyurt, E. Kuley, E. Balikçi et al., "Effect of the icing with rosemary extract on the oxidative stability and biogenic amine formation in sardine (Sardinella aurita) during chilled storage," Food and Bioprocess Technology, vol. 5, no. 7, pp. 2777-2786, 2012.

[40] E. Jiménez-Martín, T. Pérez-Palacios, J. R. Carrascal, and T. A. Rojas, "Enrichment of chicken nuggets with microencapsulated omega-3 fish oil: effect of frozen storage time on oxidative stability and sensory quality," Food and Bioprocess Technology, vol. 9, no. 2, pp. 285-297, 2016.

[41] D. Cando, H. M. Moreno, C. A. Tovar, B. Herranz, and A. J. Borderías, "Effect of high pressure and/or temperature over gelation of isolated hake myofibrils," Food and Bioprocess Technology, vol. 7, no. 11, pp. 3197-3207, 2014.

[42] S. J. Hur, S. Y. Lee, and S. J. Lee, "Effects of biopolymers encapsulations on the lipid digestibility of emulsion-type sausages using a simulated human gastrointestinal digestion model," Food and Bioprocess Technology, vol. 7, no. 8, pp. 2198-2206, 2014.

[43] S. Eymard, E. Carcouët, M.-J. Rochet, J. Dumay, C. Chopin, and C. Genot, "Development of lipid oxidation during manufacturing of horse mackerel surimi," Journal of the Science of Food and Agriculture, vol. 85, no. 10, pp. 1750-1756, 2005.

[44] T. Juntachote, E. Berghofer, S. Siebenhandl, and F. Bauer, "The antioxidative properties of holy basil and galangal in cooked ground pork," Meat Science, vol. 72, no. 3, pp. 446-456, 2006.

[45] N. Belkacem, R. Djaziri, F. Lahfa, I. A. El-Haci, and Z. Boucherit, "Phytochemical screening and in vitro antioxidant activity of various Punica granatum l. Peel extracts from Algeria: a comparative study," Phytothérapie, vol. 12, no. 6, pp. 372-379, 2014.

[46] K. Barathikannan, B. Venkatadri, A. Khusro et al., "Chemical analysis of Punica granatum fruit peel and its in vitro and in vivo biological properties," BMC Complementary and Alternative Medicine, vol. 16, p. 264, 2016.

[47] M. d. S. M. Rufino, R. E. Alves, E. S. de Brito, J. Pérez-Jiménez, F. Saura-Calixto, and J. Mancini-Filho, "Bioactive compounds and antioxidant capacities of 18 non-traditional tropical fruits from Brazil," Food Chemistry, vol. 121, no. 4, pp. 996-1002, 2010.

[48] M. Abid, H. Yaich, S. Cheikhrouhou et al., "Antioxidant properties and phenolic profile characterization by LC-MS/ MS of selected Tunisian pomegranate peels," Journal of Food Science and Technology, vol. 54, no. 9, pp. 2890-2901, 2017.

[49] H. H. Orak, H. Yagar, and S. S. Isbilir, "Comparison of antioxidant activities of juice, peel, and seed of pomegranate (Punica granatum L.) and inter-relationships with total phenolic, tannin, anthocyanin, and flavonoid contents," Food Science and Biotechnology, vol. 21, no. 2, pp. 373-387, 2012.

[50] P. Ambigaipalan, A. C. de Camargo, and F. Shahidi, "Phenolic compounds of pomegranate byproducts (outer skin, mesocarp, divider membrane) and their antioxidant activities," Journal of Agricultural and Food Chemistry, vol. 64, no. 34, pp. 6584-6604, 2016.

[51] Z. Wang, Z. Pan, H. Ma, and G. G. Atungulu, "Extract of phenolics from pomegranate peels," The Open Food Science Journal, vol. 5, no. 1, pp. 17-25, 2011.

[52] S. Voravuthikunchai, A. Lortheeranuwat, W. Jeeju, T. Sririrak, S. Phongpaichit, and T. Supawita, "Effective medicinal plants against enterohaemorrhagic Escherichia coli O157:H7," Journal of Ethnopharmacology, vol. 94, no. 1, pp. 49-54, 2004.

[53] J. G. Choi, O. H. Kang, Y. S. Lee et al., "In vitro and in vivo antibacterial activity of Punica granatum peel ethanol extract against Salmonella," Evidence-Based Complementary and Alternative Medicine, vol. 2011, Article ID 690518, 8 pages, 2011.

[54] H. Hayrapetyan, W. C. Hazeleger, and R. R. Beumer, "Inhibition of Listeria monocytogenes by pomegranate (Punica granatum) peel extract in meat paté at different temperatures," Food Control, vol. 23, no. 1, pp. 66-72, 2012.

[55] S. Naz, R. Siddiqi, S. Ahmad, S. A. Rasool, and S. A. Sayeed, "Antibacterial activity directed isolation of compounds from Punica granatum," Journal of Food Science, vol. 72, pp. 341-345, 2007.

[56] N. S. Al-Zoreky, "Antimicrobial activity of pomegranate (Punica granatum L.) fruit peels," International Journal of Food Microbiology, vol. 134, no. 3, pp. 244-248, 2009.

[57] D. Prashanth, M. K. Asha, and A. Amit, "Antibacterial activity of Punica granatum," Fitoterapia, vol. 72, no. 2, pp. 171-173, 2001.

[58] S. P. Voravuthikunchai, T. Sririrak, S. Limsuwan, T. Supawita, T. Iida, and T. Honda, "Inhibitory effects of active compounds from Punica granatum pericarp on verocytotoxin production by enterohemorrhagic Escherichia coli O157: H7," Journal of Health Science, vol. 51, no. 5, pp. 590-596, 2005.

[59] K. Radha Krishnan, S. Babuskin, P. A. S. Babu et al., "Antimicrobial and antioxidant effects of spice extracts on the shelf life extension of raw chicken meat," International Journal of Food Microbiology, vol. 171, pp. 32-40, 2014.

[60] G. Villamonte, L. Pottier, and M. de Lamballerie, "Influence of high-pressure processing on the oxidative processes in pork batters: efficacy of rosemary extract and sodium ascorbate," European Food Research and Technology, vol. 243, no. 9, pp. 1567-1576, 2017.

[61] C. Sarıçoban and M. T. Yilmaz, "Effect of thyme/cumin essential oils and butylated hydroxyl anisole/butylated hydroxyl toluene on physicochemical properties and oxidative/microbial stability of chicken patties," Poultry Science, vol. 93, no. 2, pp. 456-463, 2014.

[62] S. S. Turgut, F. Işıkçı, and A. Soyer, "Antioxidant activity of pomegranate peel extract on lipid and protein oxidation in beef meatballs during frozen storage," Meat Science, vol. 129, pp. 111-119, 2017.

[63] M. Estévez, "Protein carbonyls in meat systems: a review," Meat Science, vol. 89, no. 3, pp. 259-279, 2011.

[64] S. Smaoui, K. Ennouri, A. Chakchouk-Mtibaa et al., "Relationships between textural modifications, lipid and protein oxidation and sensory attributes of refrigerated Turkey meat sausage treated with bacteriocin BacTN6 ${ }_{35}$," Food and Bioprocess Technology, vol. 10, no. 9, pp. 1655-1667, 2017. 
[65] R. H. Carvalho, E. I. Ida, M. S. Madruga, S. L. Martínez, M. Shimokomaki, and M. Estévez, "Underlying connections between the redox system imbalance, protein oxidation and impaired quality traits in pale, soft and exudative (PSE) poultry meat," Food Chemistry, vol. 215, pp. 129-137, 2017.

[66] C. Lin, C. Toto, and L. Were, "Antioxidant effectiveness of ground roasted coffee in raw ground top round beef with added sodium chloride," LWT-Food Science and Technology, vol. 60, no. 1, pp. 29-35, 2015.

[67] K. I. Sallam, M. Ishioroshi, and K. Samejima, "Antioxidant and antimicrobial effects of garlic in chicken sausage," LWT-Food Science and Technology, vol. 37, no. 8, pp. 849855, 2004.

[68] H. Yu, C. Qin, P. Zhang et al., "Antioxidant effect of apple phenolic on lipid peroxidation in Chinese-style sausage," Journal of Food Science and Technology, vol. 52, no. 2, pp. 1032-1039, 2015.

[69] X. Gu, Y. Sun, K. Tu, and L. Pan, "Evaluation of lipid oxidation of Chinese-style sausage during processing and storage based on electronic nose," Meat Science, vol. 133, pp. 1-9, 2017.

[70] L. R. B. Mariutti and N. Bragagnolo, "Influence of salt on lipid oxidation in meat and seafood products: a review," Food Research International, vol. 94, pp. 90-100, 2017.

[71] E. Botsoglou, A. Govaris, I. Ambrosiadis, D. Fletouris, and G. Papageorgiou, "Effect of olive leaf (Olea europea L.) extracts on protein and lipid oxidation in cooked pork meat patties enriched with $n-3$ fatty acids," Journal of the Science of Food and Agriculture, vol. 94, no. 2, pp. 227-234, 2014.

[72] D. Georgantelis, G. Blekas, P. Katikou, I. Ambrosiadis, and D. J. Fletouris, "Effect of rosemary extract, chitosan and $\alpha$-tocopherol on lipid oxidation and colour stability during frozen storage of beef burgers," Meat Science, vol. 75, no. 2, pp. 256-264, 2007.

[73] J.-H. Choe, A. Jang, E.-S. Lee et al., "Oxidative and color stability of cooked ground pork containing lotus leaf (Nelumbo nucifera) and barley leaf (Hordeum vulgare) powder during refrigerated storage," Meat Science, vol. 87, no. 1, pp. 12-18, 2011

[74] B. Barriuso, I. Astiasarán, and D. Ansorena, "A review of analytical methods measuring lipid oxidation status in foods: a challenging task," European Food Research and Technology, vol. 236, no. 1, pp. 1-15, 2013.

[75] H. B. El-Nashi, A. F. A. K. Abdel Fattah, N. R. Abdel Rahman, and M. M. Abd El-Razik, "Quality characteristics of beef sausage containing pomegranate peels during refrigerated storage," Annals of Agricultural Sciences, vol. 60, no. 2, pp. 403-412, 2015.

[76] T. L. McCarthy, J. P. Kerry, J. F. Kerry, P. B. Lynch, and D. J. Buckley, "Evaluation of the antioxidant potential of natural food/plant extracts as compared with synthetic antioxidants and vitamin E in raw and cooked pork patties," Meat Science, vol. 58, no. 1, pp. 45-52, 2001.

[77] A. K. Biswas, M. K. Chatli, and J. Sahoo, "Antioxidant potential of curry (Murraya koenigii L.) and mint (Mentha spicata) leaf extracts and their effect on colour and oxidative stability of raw ground pork meat during refrigeration storage," Food Chemistry, vol. 133, no. 2, pp. 467-472, 2012.

[78] M. M. Campo, G. R. Nute, S. I. Hughes, M. Enser, J. D. Wood, and R. I. Richardson, "Flavour perception of oxidation in beef," Meat Science, vol. 72, no. 2, pp. 303-311, 2006.

[79] AFNOR V01-003, Hygiene and Safety Foods-Validation of the Microbiological Shelf Life Perishable and Cooled Foods, AFNOR, Paris, France, 2004.
[80] F. Al-Juhaimi, K. Ghafoor, M. D. Hawashin, O. N. Alsawmahi, and E. E. Babiker, "Effects of different levels of Moringa (Moringa oleifera) seed flour on quality attributes of beef burgers," CyTA-Journal of Food, vol. 14, no. 1, pp. 1-9, 2016.

[81] B. C. Jayawardana, R. Liyanage, N. Lalantha, S. Iddamalgoda, and P. Weththasinghe, "Antioxidant and antimicrobial activity of drumstick (Moringa oleifera) leaves in herbal chicken sausages," LWT-Food Science and Technology, vol. 64, no. 2, pp. 1204-1208, 2015.

[82] M. D. Hawashin, F. Al-Juhaimi, I. A. M. Ahmed, K. Ghafoor, and E. E. Babiker, "Physicochemical, microbiological and sensory evaluation of beef patties incorporated with destoned olive cake powder," Meat Science, vol. 122, pp. 32-39, 2016.

[83] M. Muthukumar, B. M. Naveena, S. Vaithiyanathan, A. R. Sen, and K. Sureshkumar, "Effect of incorporation of Moringa oleifera leaves extract on quality of ground pork patties," Journal of Food Science and Technology, vol. 51, no. 11, pp. 3172-3180, 2014.

[84] D. Park, Y. L. Xiong, A. L. Alderton, and T. Ooizumi, "Biochemical changes in myofibrillar protein isolates exposed to three oxidizing systems," Journal of Agricultural and Food Chemistry, vol. 54, no. 12, pp. 4445-4451, 2006. 